\title{
LOKABASA
}

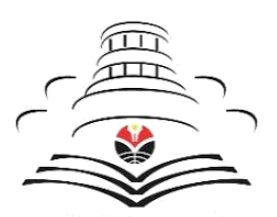

JURNAL UPI

Jurnal Kajian Bahasa, Sastra, dan Budaya Daerah serta Pengajarannya

Volume 10, No. 2, Bulan Oktober Tahun 2019, Hal. 192-203

p-2338-6193 (print) | e-2528-5904 (online)

Article URL: http://ejournal.upi.edu/index.php/lokabasa doi:10.17509/jlb.v10i2

\section{Metode Image Streaming dalam Pembelajaran Menulis Sajak}

\author{
Renaldi Rusmana, Haris Santosa Nugraha \\ Universitas Pendidikan Indonesia \\ renaldi.rusmana@upi.edu
}

\begin{abstract}
Sejarah Artikel: Diterima (11 Mei 2019); Diperbaiki (20 Juli 2019); Disetujui (3 Agustus); Pusblished (31 Oktober 2019)
\end{abstract}

Bagaimana mengutip artikel ini (dalam gaya APA): Rusmana, R, Nugraha, H. S. (2019). Metode Image Streaming dalam Pembelajaran Menulis Sajak. Lokabasa 10(2). 192-203. doi: $\underline{10.17509 / j l b . v 10 \mathrm{i} 2.21360}$

\begin{abstract}
Abstrak: Seiring berjalannya waktu, siswa menganggap pembelajaran bahasa Sunda di sekolah semakin sulit, khususnya dalam materi pembelajaran menulis sajak. Tujuan penelitian ini untuk mendeskripsikan kemampuan menulis sajak siswa sebelum dan setelah menggunakan metode Image Streaming dan perbedaan kemampuan menulis sajak siswa sebelum dan setelah menggunakan metode tersebut. Penelitian ini menggunakan pendekatan kuantitatif, dengan metode kuasi eksperimen disertai desain one group pre-test and post-test. Teknik yang digunakan adalah teknik tes dengan menggunakan soal tes kemampuan menulis sajak pada siswa kelas VII-E di SMP Negeri 2 Lembang pada tahun ajaran 2018/2019. Hasil dari penelitian ini menunjukkan: (1) kemampuan menulis sajak siswa sebelum menggunakan metode Image Streaming dengan rata-rata nilai 57,56; (2) kemampuan menulis sajak siswa setelah menggunakan metode Image Streaming dengan rata-rata nilai 72,88; (3) perbedaan kemampuan menulis sajak siswa sebelum dan setelah menggunakan metode Image Streaming dengan rata-rata nilai kemampuan awal 57,56, kemampuan akhir 72,88, maka rata-rata nilai kemampuan menulis sajak siswa mengalami peningkatan sebesar 15,32. Hasil uji hipotesis menunjukan nilai signifikansi $=0,000$. Berdasarkan hasil uji hipotesis, nilai Sig. 0,000 lebih kecil dari 0,05, artinya H1 diterima dan $\mathrm{H} 0$ ditolak. Oleh sebab itu, dapat disimpulkan bahwa penggunaan metode Image Streaming dapat meningkatkan kemampuan menulis sajak siswa kelas VII-E di SMP Negeri 2 Lembang taun ajaran 2018-2019.
\end{abstract}

Kata Kunci: image streaming; metode pembelajaran; menulis sajak

\section{Image Streaming Method in Write Poetry}

Abstract: Over time, students consider learning Sundanese in school increasingly difficult, especially in writing poetry learning material. The purpose of this study was to describe students poetry writing abilities before and after using the Image streaming method and the difference in students poetry writing abilities before and after using the Image Streaming method. This study uses a quantitative approach, the method used is quasi-experiment with one group pre-test and post-test research design, and the technique used is poetry writing ability test. The data source of this research is the ability to write poetry of class VII-E students at SMP 2 Lembang in the 2018-2019 school year, with 34 students. The results of this study show that: (1) the ability of students to write poetry before using the Image Streaming method with an average value of 57.56; (2) the ability of students to write poetry after using the Image Streaming method with an average value of 72.88; (3) differences in students poetry writing ability before and after using the Image Streaming method with an average initial ability score of 57.56, final ability of 72.88, then the average value of students poetry writing ability has increased by 15.32. Hypothesis test results show a significance value $=0,000$. Based on the results of hypothesis testing, the value of Sig. 0,000 is smaller than 0.05, meaning $\mathrm{H1}$ is accepted and $\mathrm{HO}$ is rejected. Therefore, it can be concluded that the use of the Image Streaming method can improve the poetry writing ability of VII-E class students at SMPN 2 Lembang in the 2018-2019 school year.

Keywords: image streaming, learning method, write poetry 


\section{PENDAHULUAN}

Sewaktu-waktu siswa dituntut untuk mengungkapkan pemikiran atau pendapatnya dalam bentuk tulisan, baik dalam tugas sekolah maupun hal lainnya. Oleh karena itu, keterampilan menulis menjadi hal yang sangat penting untuk siswa, sebab keterampilan menulis selalu muncul dalam berbagai kegiatan (Rahman, 2018b, hlm. 1).

Dalam kenyataanya menulis bukan hal yang mudah, masih banyak siswa yang kesulitan dalam mengungkapkan perasaan dan pemikirannya ke dalam bentuk tulisan (Rahmawati, dkk., 2014, hlm. 5). Hal ini dipengaruhi oleh proses pembelajaran yang kurang menuntun siswa dalam menulis, akibatnya siswa kesulitan dalam mengungkapkan perasaan dan pemikiranya. Oleh sebab itu, tujuan pembelajaran tidak tercapai, khususnya pembelajaran bahasa Sunda dalam materi sajak.

Pembelajaran bahasa Sunda dirasa semakin hari semakin sulit (Wulandari, 2018). Berdasarkan wawancara yang dilaksanakan September 2018 kepada guru bahasa Sunda di SMPN 2 Lembang, salah satu permasalahan yang dialami yaitu dalam pembelajaran menulis sajak. Kurangnya kemampuan dalam mengungkapkan ide merupakan pengaruh utama yang menyebabkan sedikitnya minat menulis. Ini sejalan dengan yang dikemukakan oleh (Sulistian, 2015, hlm. 2) bahwa yang menjadi masalah dalam menulis sajak adalah siswa belum bisa mengungkapkan idenya menjadi sebuah sajak.

Sajak merupakan salah satu karya sastra yang menambah kekayaan sastra Sunda setelah datangnya pengaruh dari barat, lebih tepatnya setelah Indonesia merdeka (Ruhaliah, 2017, hlm. 79). Sajak merupakan salah satu jenis puisi atau bentuk terikat, tetapi tidak terlalu terikat oleh batasan bentuk dan aturannya, oleh karena itu sajak pada masa munculnya selalu disebut dengan sajak bebas (Iskandarwassid dalam Koswara, 2013, hlm. 91). Tidak terlalu terikat oleh aturan dikarenakan sajak tidak terikat oleh "guru lagu" dan "guru wilangan". Bentuk sajak masih belum mempunyai aturan seberapa panjang atau pendeknya sebuah sajak, ada yang hanya 4 baris, bahkan ada yang lebih dari 10 baris. Sampai saat ini para ahli belum bisa memberikan definisi yang tepat untuk sajak, pada akhirnya pembaca diberi kebebasan untuk menentukan apakah itu merupakan sajak atau bukan (Isnendes, 2010, hlm. 70).

Menulis merupakan salah satu proses mengungkapkan ide atau gagasan ke dalam bentuk paparan bahasa tulisan yang merupakan simbolsimbol bahasa (Pratama, dkk., 2014, hlm. 4). Selain ide atau gagasan, sebuah tulisan tidak jarang merupakan suatu ungkapan dari pengalaman, perasaan, dan sebagainya. Ini sejalan dengan yang dikemukakan oleh Rahman (2017, hlm. 109) bahwa menulis merupakan komunikasi, ungkapan dari pemikiran, perasaan, atau ketertarikan kepada orang lain kedalam bentuk tulisan. Dalam proses mengungkapkannyapun menulis membutuhkan konsentrasi yang kuat, dikarenakan menulis termasuk ke dalam proses berpikir tingkat tinggi. Begitupun dalam menulis sebuah sajak, konsentrasi yang kuat dibutuhkan untuk mengungkapkan pemikiran dan perasaan yang ditulis secara singkat, padat, pilihan kata, dan sebagainya.

Kegiatan menulis sajak bisa disebut sebagai proses kreatif. Menulis sajak merupakan kemampuan dalam mengungkapkan ide yang dibayangkan ke dalam sebuah tulisan dengan menggunakan bahasa yang singkat dan pilihan kata yang tepat. Kata-kata yang digunakan dalam sajak harus mempunyai kekuatan untuk mendorong imajinasi serta menjadi jembatan antara pembaca dengan dunia intuisi penyair 
(panyajak). Kegiatan menulis sajak memberikan banyak peluang untuk orang-orang yang ikut di dalamnya menjadi kreatif serta mengasah nalar, dengan mengekspresikan pikiran dan perasaannya. Utami (2013, hlm. 1) mengemukakan bahwa menulis sajak bukan sekedar ditujukan untuk menghayati dan memperkaya pemahaman pada sajak. Tetapi, dengan menulis sajak akan mengasah kepekaan perasaan, nalar, dan juga kepekaan pada masalah kemanusiaan.

Dalam pembelajaran menulis, siswa tidak hanya menerima teori mengenai menulis saja, tapi siswa dituntut untuk bisa menerapkan teori tersebut agar menghasilkan suatu karya (Utami, 2013, hlm. 2). Begitu juga dalam pembelajaran menulis sajak, siswa dituntut untuk menerapkan teori-teori yang sudah diajarkan agar menghasilkan suatu karya.

Dalam menerapkannya siswa seringkali menemui hal-hal yang menyebabkan sukarnya dalam menulis sajak. Siswa merasa kesulitan dalam memunculkan ide, menuangkan perasaan pada tulisan, serta sulitnya mengembangkan ide pun menjadi salah satu penyebabnya. Di sini peran guru dalam proses pembelajaran terbilang sangat penting. Kurangnya tingkat keterampilan menulis siswa mendorong guru untuk mencari model, strategi, metode atau media yang sesuai, agar pembelajaran lebih efektif dan menarik minat siswa. Hal ini sejalan dengan yang dikemukakan oleh Rahman (2018a, hlm. 8), bahwa guru harus bisa memilih metode atau media pembelajaran yang tepat, agar bisa mendukung berlangsungnya pembelajaran untuk mencapai tujuan pembelajaran.

Alternatif untuk mengatasi permasalahan ini adalah dengan menggunakan metode pembelajaran. Metode pembelajaran adalah cara atau tahapan yang digunakan dalam interaksi antara peserta didik dengan pendidik untuk mencapai tujuan pembelajaran yang sudah ditetapkan sesuai dengan materi pembelajaran (Afandi, dkk., 2013, hlm. 16). Selain itu, metode pembelajaran dapat diartikan strategi pembelajaran yang digunakan oleh guru sebagai media untuk mencapai tujuan pembelajaran yang sudah ditetapkan. Dengan menggunakan metode pembelajaran guru dapat menciptakan lingkungan belajar serta mengkhususkan kegiatan guru dengan siswa selama pembelajaran berlangsung (Pane \& Dasopang, 2017, hlm. 344). Selain itu, menggunakan metode yang tepat akan menentukan efektifitas dan efisiensi pembelajaran (Putri, dkk., 2017, hlm. 3). Salah satu metode yang dapat mendukung siswa agar mampu mengembangkan ide dalam menulis sajak adalah metode Image Streaming. Mengapa demikian, karena metode Image Streaming berpusat pada prinsipprinsip mengolah informasi dengan menguatkan dorongan internal atau informasi datang dari diri sendiri. Siswa diajak berkonsentrasi ke dalam pikirannya agar memunculkan suatu bayangan untuk membuat sketsa tulisan, setelah itu sketsa tulisan dideskripsikan ke dalam bentuk kalimat-kalimat. Hal ini sejalan dengan yang dikemukakan oleh Hernawan, dkk. (2018, hlm. 174), bahwa menulis merupakan kegiatan yang membutuhkan tingkat konsentrasi dan daya nalar yang tinggi.

Metode Image Streaming merupakan salah satu metode pembelajaran yang termasuk ke dalam klasifikasi metode latihan. Metode ini mengacu pada suatu proses pembelajaran dengan latihan membayangkan, bisa berupa pengalaman, kejadian, dan sebagainya (Nurharini \& Sutikno, 2017, hlm. 103). Wenger (2012, hlm. 308) mengemukakan metode Image Streaming merupakan kegiatan mengalirkan bayangan-bayangan agar muncul dan 
ada di depan mata pikiran, tetapi tidak memilih secara sadar apa yang akan dibayangkan. Ketika melihat pada bayangan-bayangan tersebut, deskripsikan dengan tepat ke dalam alat perekam. Dalam hal ini, siswa memilih kata-kata kunci untuk dijadikan sebuah sketsa tulisan. Lalu sketsa yang sudah dibuat setelah itu dikembangkan kembali menjadi sebuah kalimat.

Penelitian sebelumnya yang berkaitan dengan hal ini adalah: "Keefektifan Strategi Image Streaming dalam Pembelajaran Menulis Cerpen Pada Siswa Kelas X SMA Negeri 10 Yogyakarta" (Andini, 2013). Selain itu, penelitian lainnya yaitu: "Strategi Image Streaming dina Pangajaran Nulis Teks Pangalaman Pribadi (Studi Kuasi Eksperimen ka Siswa kelas VII-B SMP Negeri 27 Bandung Taun Ajaran 2017/2018)" (Kurniawan, 2017).

Penelitian ini dilakukan untuk menguji metode Image Streaming dalam pembelajaran menulis sajak, apakah ada perbedaan sebelum dan setelah menggunakan metode ini. Selain itu, penelitian ini dilakukan untuk memperkaya kegiatan-kegiatan yang dapat dilakukan dalam proses belajar agar mengembangkan kemampuan siswa. Secara khusus, penelitian ini mempunyai tujuan untuk memberikan wawasan serta mendeskripsikan metode pembelajaran yang bisa digunakan dalam pembelajaran menulis sajak.

\section{METODE}

Penelitian ini menggunakan pendekatan kuantitatif, dengan metode kuasi eksperimen dan desain one group pre-test post-test. Metode kuasi eksperimen merupakan penelitian yang menggunakan kelas eksperimen tanpa menggunakan kelas kontrol sebagai sumber datanya (Nazir, 2014, hlm. 73). Subjek diberi pre-test berupa tes kemampuan menulis sajak, setelah diberi tes awal selanjutnya siswa diberi perlakuan menggunakan metode Image Streaming, di akhir perlakuan siswa diberi post-test yang sama dengan pretest yaitu tes kemampuan menulis sajak. Setelah melaksanakan pre-test dan posttest, kemudian dibandingkan. Agar lebih jelas, desain penelitian ini digambarkan seperti di bawah ini.

\begin{tabular}{ccc}
\hline $\mathrm{O}_{1}$ & $\mathrm{X}$ & $\mathrm{O}_{2}$ \\
\hline Gambar 1. & $\begin{array}{c}\text { Desain penelitian one group pre- } \\
\text { test and post-test }\end{array}$ \\
(Sugiyono, & 2015 hlm. 111, Sukmadinata, 2017
\end{tabular}
hlm. 208)

Keterangan:

$\mathrm{O}_{1}=$ pre-test (sebelum diberi perlakuan)

$\mathrm{X}=$ perlakuan/diklat

$\mathrm{O}_{2}=$ post-test (setelah diberi perlakuan)

Sumber data dalam penelitian ini adalah siswa kelas VII-E SMPN 2 Lembang Taun Ajaran 2018/2019, dengan jumlah siswa 34 orang, 16 orang laki-laki dan 18 orang perempuan.

Instrumen yang digunakan dalam penelitian ini adalah soal tes kemampuan menulis sajak. Mengapa demikian, karena dengan tes hasil belajar merupakan salah satu cara untuk mengukur ketercapaian proses pembelajaran yang sudah dilaksanakan (Nugraha, 2019 hlm. 44). Tes hasil belajar dilakukan untuk mengukur kemampuan menulis sajak siswa. Pengumpulan data dilakukan sebanyak dua kali tes di antaranya sebelum (pretest) dan setelah (post-test) diberi perlakuan menggunakan metode Image Streaming.

Dalam teknik mengolah data terbagi menjadi dua tahapan analisis, yaitu uji sipat data dan uji hipotesis. Analisis data dilakukan dengan cara menggunakan aplikasi SPSS (Statistical Product and Servise Solutions). Input data yang dianalisis adalah hasil pre-test dan post-test menulis sajak siswa, selanjutnya data yang dianalisis dijabarkan dalam output hasil analisis aplikasi SPSS. Data ini dianalisis untuk 
mengetahui hasil pembelajaran menulis sajak sebelum dan setelah menggunakan mtode Image Streaming.

\section{HASIL DAN PEMBAHASAN}

Di bawah ini dipaparkan mengenai kemampuan menulis sajak siswa sebelum dan setelah menggunakan metode Image Streaming. Hasil menulis sajak dinilai berdasarkan beberapa aspek, di antaranya kesesuaian tema dengan isi, kekuatan imajinasi, diksi (pilihan kata), ejahan dan kerapihan tulisan.

\section{Kemampuan Menulis Sajak Siswa Sebelum Menggunakan Metode Image Streaming}

Nilai tertinggi dari hasil pre-test yaitu 77, sedangkan nilai terendahnya yaitu 38. Kemampuan menulis sajak siswa sebelum menggunakan metode Image Streaming menunjukan nilai ratarata 57,56 dari kriteria penilaian menulis sajak 70, yang artinya kemampuan rata-rata siswa tergolong belum mampu. Dari 34 siswa, nilai siswa yang terbilang mampu menulis sajak ada 5 orang. Sedangkan siswa yang terbilang belum mampu menulis sajak ada 29 orang, dikarenakan belum mencapai kriteria yang sudah ditentukan. Apabila dipersentasekan, dari 34 siswa yang mampu menulis sajak yaitu $15 \%$, sedangkan yang belum mampu menulis sajak yaitu $85 \%$.

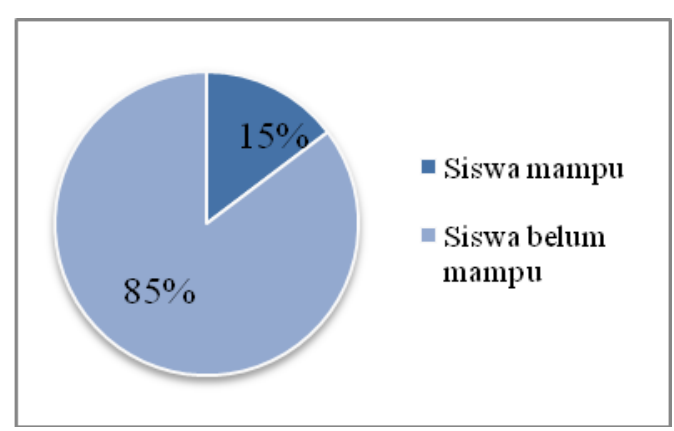

Gambar 2. Grafik Perséntase Hasil Kemampuan Menulis Sajak Siswa Sebelum Menggunakan Metode Image Streaming
Kemampuan menulis sajak siswa berdasarkan aspek kesesuaian tema dengan isi, termasuk kategori cukup dengan skala rata-rata $3,26 \quad(65 \%)$. Kemampuan siswa terbilang cukup dalam membuat isi sajak agar sesuai dengan tema.

Kemampuan menulis sajak siswa berdasarkan aspek kekuatan imajinasi, termasuk kategori kurang, dengan skala rata-rata 2,82 (56\%). Kekuatan imajinasi dari sajak yang dibuat oleh siswa masih kurang dalam merangsang imajinasi pembaca agar isi sajak tergambarkan.

Kemampuan menulis sajak siswa berdasarkan aspek diksi (pilihan kata), termasuk kategori kurang dengan skala rata-rata 2,41 (48\%). Dalam aspek ini siswa masih kebingungan dalam menggunakan bahasa Sunda yang tepat, masih banyak siswa yang menggunakan campuran bahasa Indonesia, akibatnya pilihan kata menjadi kurang tepat.

Kemampuan menulis sajak siswa berdasarkan aspek ejahan, termasuk kategori kurang, dengan skala rata-rata 2,56 (51\%). Dalam aspek ini siswa masih kebingungan dalam menulis kata imbuhan dan kata majemuk, yang seharusnya disatukan menjadi dipisahkan, dan begitu juga sebaliknya. Siswa pun masih kesulitan membedakan é, e, dan eu.

Kemampuan menulis sajak siswa berdasarkan aspek kerapihan tulisan, termasuk kategori cukup, dengan skala rata-rata 3,26 (65\%). Dalam aspek ini, rata-rata tulisan siswa terbilang rapih dan dapat dimengerti.

\section{Kemampuan Menulis Sajak Siswa Setelah Menggunakan Metode Image Streaming}

Nilai tertinggi dari hasil post-test yaitu 84, sedangkan nilai terendahnya yaitu 56. Kemampuan menulis sajak siswa setelah menggunakan metode Image Streaming menunjukan rata-rata 
72,88 dari kriteria penilaian menulis sajak 70, yang artinya rata-rata siswa tergolong mampu. Dari 34 siswa, nilai siswa yang terbilang mampu menulis sajak ada 28 orang. Sedangkan siswa yang terbilang belum mampu menulis sajak ada 6 orang, dikarenakan belum memenuhi kriteria yang sudah ditentukan. Bila dipersentasekan, dari 34 siswa yang mampu menulis sajak yaitu $82 \%$, sedangkan siswa yang belum mampu menulis sajak yaitu $18 \%$.

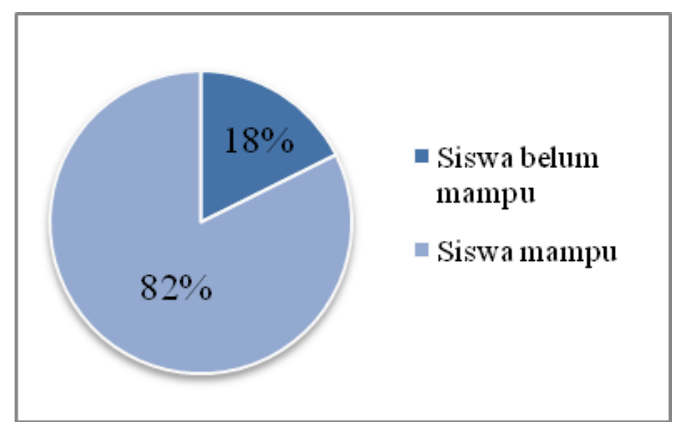

Gambar 3. Grafik Persentase Hasil Kemampuan Menulis Sajak Siswa Setelah Menggunakan Metode Image Streaming

Kemampuan menulis sajak siswa berdasarkan aspek kesesuaian tema dengan isi, termasuk kategori bagus, dengan skala rata-rata 4,12 (82\%). Secara keseluruhan siswa terbilang sudah mampu dalam membuat isi sajak agar sesuai dengan tema.

Kemampuan menulis sajak siswa berdasarkan aspek kekuatan imajinasi, termasuk kategori cukup bagus, dengan skala rata-rata $3,79(76 \%)$. Imajinasi dalam sajak yang dibuat oleh siswa terbilang cukup bagus, rata-rata dari tiap sajak siswa memberi rangsangan agar isi sajak tergambarkan.

Kemampuan menulis sajak siswa berdasarkan aspek diksi (pilihan kata), termasuk kategori cukup dengan skala rata-rata 3,21 (64\%). Siswa terbilang cukup dalam pemilihan kata bahasa Sunda yang tepat, meskipun dalam ejahan ada beberapa kesalahan. Pilihan kata dan penempatan setiap kata terbilang cukup, meskipun masih ada satu atau dua kata yang campuran dari bahasa Indonesia.

Kemampuan menulis sajak siswa berdasarkan aspek ejahan, termasuk kategori kurang-cukup, dengan skala rata-rata 2,91 (58\%). Meskipun skala rata-rata kemampuan siswa dalam aspek ejahan meningkat, tetapi dalam aspek ini masih dalam kategori kurang-cukup ketika menulis kata dengan ejahan yang benar.

Kemampuan menulis sajak siswa berdasarkan aspek kerapihan tulisan, termasuk kategori cukup-bagus, dengan skala rata-rata $3,82(76 \%)$. Rata-rata tulisan siswa terbilang rapi dan dapat dimengerti, serta siswa sudah cukup bisa dalam menghindari coretancoretan.

\section{Perbedaan Kemampuan Menulis Sajak Siswa Sebelum dan Setelah Menggunakan Metode Image Streaming}

Berdasarkan hasil pre-test menulis sajak siswa, dapat disimpulkan bahwa kemampuan siswa dalam menulis sajak tergolong belum mampu. Nilai tertinggi dari hasil pe-test yaitu 77, sedangkan nilai terendahnya yaitu 38. Dari 34 siswa, nilai siswa yang terbilang mampu menulis sajak ada 5 orang (15\%), sedangkan siswa yang terbilang belum mampu menulis sajak ada 29 orang (85\%). Dari hasil post-test menulis sajak siswa, dapat disimpulkan bahwa kemampuan siswa dalam menulis sajak tergolong mampu. Nilai tertinggi dari hasil post-test yaitu 84, sedangkan nilai terendahnya yaitu 56 . Dari 34 siswa, yang terbilang mampu menulis sajak ada 28 orang (82\%), sedangkan siswa yang terbilang belum mampu menulis sajak ada 6 orang (18\%). Dapat dilihat nilai terendah yang awalnya 38, setelah menggunakan metode Image Streaming meningkat menjadi nilai terendahnya 56 , dan nilai 
tertinggi yang awalnya 77, setelah menggunakan metode Image Streaming meningkat menjadi nilai tertingginya 84.

Kemampuan menulis sajak siswa mengalami beda yang cukup signifikan setelah siswa mendapatkan pembelajaran menulis sajak menggunakan metode tersebut. Dari hasil penelitian ini diketahui kemampuan menulis sajak siswa sebelum menggunakan metode Image Streaming menunjukkan rata-rata 57,56 (58\%), yang artinya rata-rata kemampuan menulis sajak siswa tergolong kategori belum mampu. Sedangkan kemampuan menulis sajak siswa setelah menggunakan metode Image Streaming menunjukkan rata-rata $72,88(73 \%)$, yang artinya rata-rata kemampuan menulis sajak siswa tergolong sudah mampu. Dari hasil akhirnya diketahui bahwa rata-rata kemampuan menulis sajak siswa meningkat 15,32 (15\%).

Di bawah ini dipaparkan mengenai setiap aspek dalam penilaian hasil menulis sajak siswa sebelum dan setelah menggunakan metode Image Streaming.

\section{Kesesuaian tema dengan isi}

Berdasarkan aspek kesesuaian tema dengan isi, kemampuan awal menulis sajak siswa termasuk kategori cukup dengan skala rata-rata $3,26(65 \%)$. Siswa terbilang cukup mampu dalam membuat isi sajak agar sesuai dengan tema. Kemampuan ahir menulis sajak siswa meningkat menjadi kategori bagus, dengan skala rata-rata 4,12 (82\%). Seluruh siswa terbilang sudah mampu dalam membuat isi sajak agar sesuai dengan tema. Dari aspek ini, skala rata-rata kemampuan menulis sajak siswa dalam aspek kesesuaian tema dengan isi meningkat $0,86(17 \%)$.

\section{Kekuatan Imajinasi}

Berdasarkan aspek kekuatan imajinasi, kemampuan awal menulis sajak siswa termasuk kategori kurangcukup, dengan skala rata-rata 2,82 (56\%). Kekuatan imajinasi dari sajak yang dibuat oleh siswa masih kurang dalam merangsang imajinasi pembaca agar isi sajak tergambarkan. Kemampuan akhir menulis sajak siswa termasuk kategori cukup-bagus, dengan skala rata-rata 3,79 (76\%). Kekuatan imajinasi dalam sajak yang dibuat oleh siswa terbilang cukup bagus, rata-rata kekuatan imajinasi dari setiap sajak memberikan rangsangan imajinasi pada pembaca agar isi sajak bisa tergambar atau terbayangkan. Dari aspek ini, skala rata-rata kemampuan menulis sajak siswa dalam aspek kekuatan imajinasi meningkat 0,97 (19\%).

\section{Diksi (Pilihan Kata)}

Berdasarkan aspek diksi (pilihan kecap), kemampuan awal menulis sajak siswa termasuk kategori kurang, dengan skala rata-rata 2,41 (48\%). Dalam aspek ini siswa masih kebingungan dalam menggunakan bahasa Sunda yang tepat, masih banyak siswa yang mencampurkan kata bahasa Sunda dengan bahasa Indonesia dalam menulis sajaknya, akibatnya pemilihan kata menjadi kurang tepat. Kemampuan akhir menulis sajak siswa termasuk kategori cukup, dengan skala rata-rata 3,21 (64\%). Kemampuan siswa terbilang cukup dalam menggunakan bahasa Sunda yang tepat, meskipun dalam ejahannya masih ada beberapa kesalahan. Pilihan kata serta penempatan setiap kata terbilang cukup tepat, meskipun masih ada satu atau dua kata serapan. Dari aspek ini, skala rata-rata kemampuan menulis sajak siswa dalam aspek diksi (pilihan kata) meningkat 0,8 $(16 \%)$. 


\section{Ejahan}

Berdasarkan aspek ejahan, kemampuan awal menulis sajak siswa termasuk kategori kurang-cukup, dengan skala rata-rata $2,56(51 \%)$. Dalam aspek ini, siswa masih kebingungan dalam menulis kata imbuhan dan kata majemuk, kata yang seharusnya disatukan menjadi dipisahkan, begitu juga sebaliknya. Siswa pun masih kebingungan dalam membedakan é, e, eu. Kemampuan akhir menulis sajak siswa termasuk kategori kurangcukup, dengan skala rata-rata 2,91 (58\%). Meskipun skala rata-rata kemampuan siswa dalam aspek ejahan meningkat, aspek ini masih tetap dalam kategori kurang-cukup ketika menulis kata dengan ejahan yang benar. Dari aspek ini, skala rata-rata kemampuan menulis sajak siswa dalam aspek ejahan meningkat $0,35(7 \%)$.

\section{Kerapihan Tulisan}

Berdasarkan aspek kerapihan tulisan, kemampuan awal menulis sajak siswa termasuk kategori cukup, dengan skala rata-rata 3,26 (65\%). Dalam aspek ini, rata-rata tulisan siswa terbilang rapih dan dapat dimengerti. Kemampuan akhir menulis sajak siswa termasuk kategori cukup-bagus, dengan skala rata-rata $3,82(76 \%)$. Rata-rata tulisan siswa terbilang rapih dan dapat dimengerti, serta siswa mampu menghindari coretan-coretan. Dari aspek ini, skala rata-rata kemampuan menulis sajak siswa dalam aspek kerapihan tulisan meningkat 0,56 (11\%).

Untuk lebih jelasnya, beda rata-rata kemampuan menulis sajak siswa sabelum dan setelah menggunakan metode Image Streaming dalam setiap aspeknya, digambarkan dalam diagram di bawah ini.

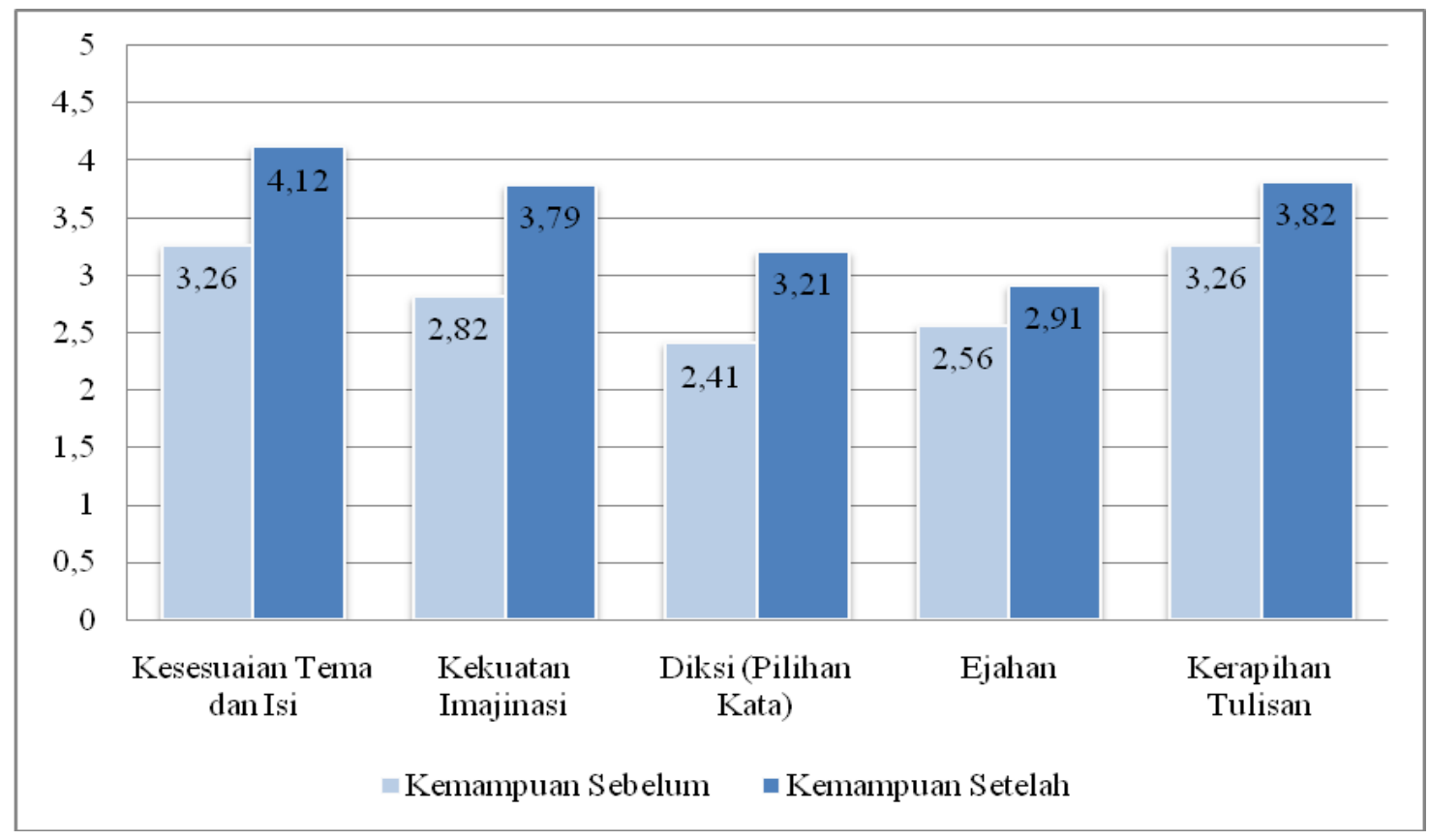

Gambar 4. Diagram Kemampuan Menulis Sajak Siswa Sebelum dan Setelah Menggunakan Metode Image Streaming Berdasarkan Tiap Aspek yang Dinilainya

Uji Perbedaan antara Kemampuan

Menulis Sajak Siswa Sebelum dan Setelah Menggunakan Metode Image Streaming
Untuk menguji perbedaan antara kemampuan menulis sajak siswa sebelum dan setelah menggunakan metode Image Streaming dilakukan uji 
normalitas dan uji hipotesis. Uji normalitas dilakukan untuk mengetahui sifat distribusi data, apakah data mempunyai distribusi normal atau tidak. Uji hipotesis dilakukan untuk membuktikan diterima atau ditolaknya hipotesis penelitian yang sudah ditentukan. Selain itu, uji hipotesis dilakukan untuk mengetahui apakah ada perbedaan atau tidak antara kemampuan menulis sajak siswa sebelum dan setelah menggunakan metode Image Streaming.

Berdasarkan uji normalitas, nilai sig. data pre-test yaitu 0,352 . Nilai sig. data pre-test lebih tinggi dari 0,05 , oleh karena itu $\mathrm{H}_{0}$ diterima dan $\mathrm{H}_{1}$ ditolak. Artinya data pre-test mempunyai distribusi data normal. Jika dilihat dari garis kenormalannya, titik-titik pencar mengikuti atau mendekati garis diagonalnya, oleh karena itu dapat disimpulkan bahwa distribusi data pretest normal.

Nilai sig. data post-test yaitu 0,003 . Nilai sig. data post-test lebih rendah dari 0,05 , oleh karena itu $\mathrm{H}_{0}$ ditolak dan $\mathrm{H}_{1}$ diterima. Artinya data post-test mempunyai distribusi data tidak normal. Jika dilihat dari garis kenormalannya, titik-titik pencar tidak mengikuti atau tidak mendekati garis diagonal, oleh karena itu dapat disimpulkan bahwa distribusi data post-test tidak normal.

Dikarenakan salah satu data mempunyai distribusi tidak normal, oleh karena itu dalam uji hipotesisnya menggunakan uji statistik nonparametric dengan menggunakan tes tipe Wilcoxon. Berdasarkan uji statistik non-parametric, hasilnya menunjukkan nilai Asymp. Sig. (2-tailed) yaitu 0,000 $<0,05$. Dikarenakan nilai Asymp. Sig. (2-tailed) lebih rendah dari 0,05, artinya $\mathrm{H}_{1}$ diterima dan $\mathrm{H}_{0}$ ditolak. Oleh karena itu, dapat disimpulkan bahwa terdapat beda yang signifikan antara kemampuan menulis sajak siswa sebelum dan setelah menggunakan metode Image Streaming. Artinya metode Image
Streaming dapat meningkatkan kemampuan menulis sajak siswa kelas VII-E SMPN 2 Lembang taun ajaran 2018-2019.

\section{KESIMPULAN}

Penelitian ini mendeskripsikan tentang metode Image Streaming dalam pembelajaran menulis sajak, yang dilakukan pada siswa kelas VII-E di SMPN 2 Lembang taun ajaran 20182019. Hasilnya dapat disimpulkan seperti di bawah ini.

Kemampuan menulis sajak siswa sebelum menggunakan metode Image Streaming menunjukkan rata-rata 57,56 dari kriteria penilaian menulis sajak 70 , artinya rata-rata siswa tergolong belum mampu. Nilai tertinggi dari hasil pretest yaitu 77, sedangkan nilai terendahnya yaitu 38. Sabelum menggunakan metode Image Streaming, kemampuan menulis sajak siswa dalam aspek kesesuaian tema dengan isi, kekuatan imajinasi, dan kerapihan tulisan termasuk dalam kategori cukup. Sedangkan dalam aspek diksi (pilihan kata) dan ejahan termasuk dalam kategori kurang.

Kemampuan menulis sajak siswa setelah menggunakan metode Image Streaming menunjukkan rata-rata 72,88 dari kriteria penilaian menulis sajak 70 , artinya rata-rata siswa tergolong mampu. Nilai tertinggi dari hasil posttest yaitu 84, sedangkan nilai terendahnya yaitu 56. Setelah menggunakan metode Image Streaming, kemampuan menulis sajak siswa dalam aspek kesesuaian tema dengan isi, kekuatan imajinasi, dan kerapihan tulisan, termasuk kategori bagus. Sedangkan dalam aspek diksi (pilihan kata) dan ejahan termasuk kategori cukup.

Terdapat perbedaan yang signifikan antara kemampuan menulis sajak siswa kelas VII-E SMPN 2 Lembang sebelum dan setelah menggunakan metode Image Streaming. Ini dibuktikan oleh 
hasil uji hipotesis yang menunjukkan nilai Asymp. Sig. (2-tailed) lebih rendah dari 0,05. Oleh karena itu, dapat disimpulkan bahwa metode Image Streaming dapat meningkatkan kemampuan menulis sajak siswa kelas VII-E SMPN 2 Lembang taun ajaran 20182019.

\section{UCAPAN TERIMA KASIH}

Puji dan syukur penulis panjatkan kepada Tuhan yang Maha Esa, dengan rahmat dan hidayah-Nya penulis dapat melaksanakan penelitian ini dengan lancar. Penulis mengucapkan terima kasih kepada semua pihak yang telah mendukung dalam pelaksanaan sampai dengan selesainya penelitian ini.

\section{CATATAN PENULIS}

Penulis menyatakan bahwa tidak ada konflik kepentingan terkait publikasi artikel ini. Penulis mengkonfirmasi bahwa data dan artikel ini bebas plagiarisme.

\section{PUSTAKA RUJUKAN}

Afandi, M., Chamalah, E., \& Wardani, O. P. (2013). Model dan Metode Pembelajaran di Sekolah. Retrieved from http://cyber.unissula.ac.id/journal/d osen/publikasi/211313015/9230sus un_isi_dan_daftar_pustaka_buku_ model_edit_.pdf

Andini, N. L. (2013). Keefektifan Strategi Image Streaming dalam Pembelajaran Menulis Cerpen Pada Siswa Kelas X Sma Negeri 10 Yogyakarta. Universitas Negeri Yogyakarta.

Hernawan, H., Widyastuti, T., \& Nugraha, H. S. (2018). Model Writing Workshop dalam Penulisan Proposal Skripsi Mahasiswa Departemen Pendidikan Bahasa Daerah FPBS UPI. LOKABASA, 8(2), 173. https://doi.org/10.17509/jlb.v8i2.1
5591

Isnendes, R. (2010). Teori Sastra. Bandung: Jurusan Pendidikan Bahasa Daerah-FPBS-UPI.

Koswara, D. (2013). Racikan Sastra: Pangdeudeul Bahan Perkuliahan Sastra Sunda. Bandung: Teu Diterbitkeun.

Kurniawan, F. W. (2017). Strategi Image Streaming dina Pangajaran Nulis Teks Pangalaman Pribadi (Studi Kuasi Eksperimen ka Siswa Kelas VII-B SMP Negeri 27 Bandung Taun Ajaran 2018/2019). Universitas Pendidikan Indonesia.

Nazir, M. (2014). Metode Penelitian. Bogor: Ghalia Indonesia.

Nugraha, H. S. (2019). Kualitas Soal Ujian Departemen Pendidikan Bahasa Daerah FPBS UPI Tahun Akademik 2016/2017. LOKABASA, $9(1), \quad 43$. https://doi.org/10.17509/jlb.v9i1.1 5617

Nurharini, A., \& Sutikno, P. Y. (2017). Metode Image Streaming dalam Meningkatkan Kreatifitas Aransemen Musik. Jurnal Kreatif: Jurnal Kependidikan Dasar, 7(2), 101-106. Retrieved from https://journal.unnes.ac.id/nju/inde x.php/kreatif/article/view/9372

Pane, A., \& Dasopang, M. D. (2017). Belajar dan Pembelajaran. FITRAH:Jurnal Kajian Ilmu-Ilmu Keislaman, 3(2), 333. https://doi.org/10.24952/fitrah.v3i2 .945

Pratama, T. A., Kuswari, U., \& Ruhaliah. (2014). Média Photostory dina Ngaronjatkeun Kamampuh Nulis Sajak (Studi Kuasi Ékspérimén ka Siswa Kelas VII-14 SMP Negeri 9 Bandung Tahun Ajaran 2013/2014). DANGIANG SUNDA, 2(2). Retrieved from http://antologi.upi.edu/main/antolo gi/C025/view/199/mÉdiaphotostory-dina-ngaronjatkeun- 
kamampuh-nulis-sajak-studi-kuasiÉkspérimén-ka-siswa-kelas-vii-14smp-negeri-9-bandung-tahunajaran-2013/2014-.html

Putri, A. M. S., Kuswari, U., \& Haerudin, D. (2017). Metode Mind Mapping (Peta Pikiran) dalam Pembelajaran Menyampaikan Laporan Perjalanan (Penelitian Kuasi Eksperimen terhadap Siswa Kelas VIII-B SMP Negeri 10 Bandung Tahun Ajaran 2016/2017). DANGIANG SUNDA, 5(1), 1-10. Retrieved from http://antologi.upi.edu/main/antolo gi/C025/view/1155/metode-mindmapping--peta-pikiran-dalampembelajaran-menyampaikanlaporan-perjalanan-penelitiankuasi-eksperimen-terhadap-siswakelas-viii-bsmp-negeri-10bandung-tahun-ajaran-2016/2017.html

Rahman. (2017). Model Mengajar \& Bahan Pembelajaran. Jatinangor: Alqaprint.

Rahman. (2018a). Keterampilan Guru Abad 21 dalam Variabel Penguasaan Media Elektronik. Retrieved June 14, 2019, from Direktori UPI website: https://scholar.google.co.id/citation

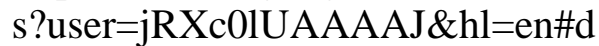
=gs_md_cita-

$\mathrm{d} \& \mathrm{u}=\% 2 \mathrm{Fcitations} \% 3$ Fview_op $\%$ 3Dview_citation\%26hl\%3Den\%26 user\%3DjRXc01UAAAAJ\%26citat ion_for_view\%3DjRXc01UAAAA J\%3ABJrgspguQaEC\%26tzom\%3 D-420

Rahman. (2018b). Writing Prose Through Think Talk Write Model Based On Video In Elementary School. Retrieved June 20, 2019, from Direktori UPI website: https://scholar.google.co.id/citation

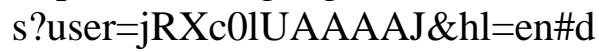
=gs_md_cita$\mathrm{d} \& \mathrm{u}=\% 2$ Fcitations $\% 3$ Fview_op $\%$ 3Dview_citation\%26hl\%3Den\%26
user\%3DjRXc0lUAAAAJ\%26citat ion_for_view\%3DjRXc0lUAAAA J\%3ATaaCk18tZOkC\%26tzom\%3 D-420

Rahmawati, R., Kuswari, U., \& Sutisna, A. (2014). Media Video dalam Pembelajaran Menulis Sajak (Studi Kuasi Eksperimen kepada Siswa Kelas VII A SMPN 2 Selajambe Kabupaten Kuningan Tahun Ajaran 2013/2014). DANGIANG SUNDA, 3(1), 1-11. Retrieved from

http://antologi.upi.edu/main/antolo gi/C025/view/29/media-videodalam-pembelajaran-menulissajak-studi-kuasi-eksperimen-kesiswa-kelas-vii-a-smpn-2selajambe-kabupaten-kuningantahun-ajaran-2013/2014-.html

Ruhaliah. (2017). Sajarah Sastra Sunda. Bandung: UPI Press.

Sugiyono. (2015). Metode Penelitian Pendidikan (Pendekatan Kuantitatif, Kualitatif dan $R \& D)$. Bandung: Alfabeta.

Sukmadinata, N. S. (2017). Metode Penelitian Pendidikan. Bandung: Remaja Rosdakarya.

Sulistian, A. T. (2015). Modél Invéstigasi Kelompok pikeun Ngaronjatkeun Kamampuh Nulis Sajak: Studi Kuasi Eksperimen ka Siswa Kelas XI MIA 2 SMA Pasundan 8 Bandung Taun Ajaran 2014/2015. Universitas Pendidikan Indonesia.

Utami, M. (2013). Metode Field Trip dalam Pembelajaran Menulis Puisi di Smpn 3 Lembang. Bahtera Bahasa, 1(1), 1-13. Retrieved from http://ejournal.upi.edu/index.php/P SPBSI/article/view/446

Wenger, W. (2012). Beyound Teaching and Learning. Memadukan Quantum Teaching dan Learning, (terjemahan). Bandung: Nuansa Cendekia.

Wulandari, C. R. (2018, September). 
Kurikulum Bahasa Sunda di Sekolah Harus Diperbaiki. Pikiran

Rakyat. Retrieved from https://www.pikiran- rakyat.com/pendidikan/2018/09/19

/kurikulum-bahasa-sunda-disekolah-harus-diperbaiki-430374 